\title{
Arbuscular mycorrhizal colonization in Asteraceae from white sand savannas, in Pinar del Río, Cuba
}

\author{
Raquel Milagros Rodríguez-Rodríguez, ${ }^{1,2}$, Pedro Herrera ${ }^{1}$ \& Eduardo Furrazola ${ }^{1}$ \\ ${ }^{1}$ Instituto de Ecología y Sistemática: Carretera de Varona $\mathrm{Km} 3^{1 /}$, \\ Capdevila, Boyeros, La Habana 19 C.P. 11900, Cuba \\ ${ }^{2}$ Corresponding author: Raquel Milagros Rodríguez-Rodríguez, e-mail: ode@ecologia.cu; \\ ode.raquel@gmail.com
}

RODRÍGUEZ-RODRÍGUEZ, R.M., HERRERA, P. \& FURRAZOLA, E. Arbuscular mycorrhizal colonization in Asteraceae from white sand savannas, in Pinar del Río, Cuba. Biota Neotrop.(13)3:http://www. biotaneotropica.org.br/v13n3/en/abstract?article+bn03013032013

\begin{abstract}
Asteraceae family shows a great diversity in Cuba and presents threatened taxons in high number. Pinar del Río has 19 threatened species belonging to this family and three of them are characteristic of a sandy (quartzitic) soil at the Reserva Florística Manejada San Ubaldo-Sabanalamar (Floristic Reserve San Ubaldo-Sabanalamar). The arbuscular mycorrhizal status and colonization rate in Aster grisebachii, Erigeron bellidiastroides, Erigeron cuneifolius, Pectis juniperina and Sachsia polycephala (Asteraceae) from this Reserve was determined in October 2009 and April 2010, during hydrologic rainy and dry period, respectively. All species were mycotrophic in both periods with a high percentage of colonization rates, between 66 and 100\% in rainy period and between 84 and $100 \%$ in dry period. Vesicles, arbuscules, spores, hyphal and arbuscular coils of arbuscular mycorrhizae were observed. Paris -type and Arum -type morphologies (both) were observed indistinctly in all the species, and Intermediate type was observed only in Aster grisebachii and Erigeron bellidiastroides, which could be a hint that these species are colonized by more than one fungal species, and therefore enhancing the relevance of fungal identity as a considerable character in the morphology association. Also, septate hyphae and microsclerotium of dark septate endophytes were identifyed inside the roots of all the species.
\end{abstract}

Keywords: internal morphology, Paris-type, Arum-type, Intermediate type, quartzitic sands, dark septate endophytes.

RODRÍGUEZ-RODRÍGUEZ, R.M., HERRERA, P. \& FURRAZOLA, E. Colonización micorrízica arbuscular en Asteraceae de las sabanas de arenas blancas, de Pinar del Río, Cuba. Biota Neotrop.(13)3:http://www. biotaneotropica.org.br/v13n3/pt/abstract?article+bn03013032013

Resumen: La familia Asteraceae muestra una gran diversidad en Cuba y presenta un elevado número de taxones amenazados. Pinar del Río cuenta con 19 especies amenazadas pertenecientes a esta familia, de las cuales tres son características de los suelos arenosos cuarcíticos de la Reserva Florística Manejada San Ubaldo-Sabanalamar. Se determinó el estatus micorrízico arbuscular y la tasa de colonización de Aster grisebachii, Erigeron bellidiastroides, Erigeron cuneifolius ,Pectis juniperina y Sachsia polycephala (Asteraceae) presentes en esta Reserva, en octubre del 2009 y abril del 2010, durante los períodos hidrológicos húmedo y seco, respectivamente. Todas las especies estaban micorrizadas en ambos períodos con elevados porcentaje de colonización micorrízica, entre 66 y $100 \%$ en el período lluvioso y entre 84 y 100\% en el período seco. Se identificaron vesículas, arbúsculos, esporas, enrollados hifales y arbusculares característicos de las micorrizas arbusculares. Los tipos morfológicos Paris y Arum (ambos) fueron observados indistintamente en todas las especies, y el tipo Intermedio solo se observó en Aster grisebachii y Erigeron bellidiastroides, lo cual sugiere la colonización de estas especies por más de una especie fúngica y con ello la importancia de la identidad fúngica en la determinación de la morfología de la asociación. Se identificaron además, hifas septadas y microesclerosios de endófitos oscuros septados en el interior de las raíces de todas las especies estudiadas.

Palabras claves: morfología interna, tipo Paris, tipo Arum, tipo Intemedio, arenas cuarcíticas, endófitos oscuros septados. 


\section{Introduction}

Around $80 \%$ of species and $92 \%$ of families of terrestrial plants are known to be mycorrhizal (Wang \& Qiu 2006) and the arbuscular type being the most common and ancestral (Trappe 1981, Brundrett 2002, Wang \& Qiu 2006).

According to their internal morphology, arbuscular mycorrhizae are divided in two main types: Arum-Type and Paris-Type, which were described in these plant genera by Gallaud $(1904,1905)$ (cited by Dickson 2004 and Dickson et al. 2007). Smith \& Smith (1997) recognize "Intermediate" morphology when both structural types are recorded in the same plant species (mixture of Arum and Paris types) and "Both" when they are observed in different species or genera within the same family. However Dickson (2004) use intermediate morphology to describe structures which are between Arum and Paris morphologies and claimed the existence of continuum of mycorrhizal structures from Arum to Paris, depending upon both the host plant and the fungus. Dickson et al. (2007) use "Intermediate" for families with characteristics of both Arum and Paris structures within the same genera, whereas "Both" relates to the situation when Arum and Paris type morphologies, as strictly defined, have been observed within that family.

Cuban research on the mycorrhizal status of terrestrial plants are restricted to works by Ferrer \& Herrera $(1985,1988)$, also in the province of Pinar del Río (nowadays Artemisa and Pinar del Río). So far there are no reports about the structural diversity of arbuscular mycorrhizae in Cuban plants.

The family Asteraceae shows a great diversity in Cuba and in turn presents elevated number of threatened taxons. Pinar del Río has 19 threatened species inside this family, three of them characteristic in the Reserva Florística Manejada (RFM) San Ubaldo-Sabanalamar: Aster grisebachii Britton, Erigeron bellidiastroides Griseb. and Pectis juniperina Rydb. These species, in addition to Erigeron cuneifolius DC and Sachsia polycephala Griseb, also presents in this ecosystem, were evaluated in this study.

Our objective was determine arbuscular mycorrhizal status and describe the internal morphology of the AM symbiosis in five species of Asteraceae (Compositae) from the white sand (quartzitic) savannas in Southwestern Pinar del Río and their relation to previous reports in this family.

\section{Material and methods}

\section{Characterization of research site}

RFM San Ubaldo-Sabanalamar (W 843'15”, N 22॰9'2” y W 84'57'23", N 22 $3^{\circ}$ '54”), in Southwestern Pinar del Río, Cuba, is included in the District Sabaloense according to Borhidi (1996) and the main characteristic of which is a sandy (quartzitic) soil with a low nutrient contents and very acid. This, together with alternating rainy and drought seasons, are the contributing factors for the establishment of a highly specialized flora and very high endemism (Urquiola et al. 2010). Field work took place in October 2009 and April 2010 at a disturbed zone inside the Reserve during hydrologic rainy and dry period, respectively.

\section{Species tested}

Five herbaceous species of the family Asteraceae were selected, three of them endemics of Western Cuba: Aster grisebachii, Erigeron bellidiastroides (both present in Pinar del Río and Isla de la Juventud) and Pectis juniperina (only from Pinar del Río) and two nonendemics: Erigeron cuneifolius (also in West Indies) and Sachsia polycephala (also recorded from Bahamas and Hispaniola). Aster grisebachii and Erigeron bellidiastroides are considered endangered (EN) and Pectis juniperina in critical threat (CR) according to IUCN criteria. Erigeron bellidiastroides is considered near threatened (NT) and Erigeron cuneifolius and Sachsia polycephala least concern (LC) according to the Group of Experts on Cuban Plants (GEPC) of the Commission for the Survival of Species (CSE).

\section{Mycorrhizal variables assessed}

Samples from root systems of five individuals $\mathrm{x}$ species were taken. Roots less than $2 \mathrm{~mm}$ thick were washed, dried and cut into pieces ca. $1 \mathrm{~cm}$ long and mixed so as to have a single sample/species. Fractions ca. $0.5 \mathrm{~g}$ were cleared and stained following Phillips \& Hayman (1970). We took only five individuals x species because their populations are only a few and of restricted distribution.

The arbuscular mycorrhizal status and colonization rate under the stereoscopic microscope were determined. Mycorrhizal colonization was estimated in accordance with the intersection method (Giovannetti \& Mosse 1980). Characteristic structures of MA inside the roots were examined and identified under compound microscope with magnifying from 200 up to $1000 \mathrm{x}$ (both microscopes belong to the trade mark CARL ZEISS model AXIOSKOP 2 Plus). Based upon the structures, the internal morphology was determined.

\section{Results}

All the species were mycorrhizal in both periods and colonization rate were between 65 and $100 \%$ in October and between 85 and $100 \%$ in April (Table 1.). The colonization average of all species in both seasons was higher than $60 \%$; however, the values of mycorrhizal colonization in all species during the dry season were equal or bigger than the values observed during the rainy season. The characteristic structures of arbuscular mycorrhizae were found in all species: arbuscules, hyphal coils and intraradical vesicles, three of

Table 1. Percentage of Arbuscular Mycorrhizal Colonization (\%CM) and intraradical fungal structures of arbuscular mycorrhizae in tested species: (A) arbuscules, (HC) hyphal coils, (AC) arbuscular coils, (S) spores, (V) vesicles and (LH+HC) longitudinal hypha+ hyphal coils. Intraradical fungal structures of dark endophyte: (SH) septate hyphae and (MS) microsclerotium. Morphological type (MT) of arbuscular mycorrhizal colonization: both (Arum and Paris Type) and Intermediate Type.

Tabla 1. Porcentajes de colonización micorrízico arbuscular $(\% \mathrm{CM})$ y estructuras fúngicas intrarradicales de las micorrizas arbusculares en las especies evaluadas: (A) arbúsculos, (HC) enrollados hifales, (AC) enrollados arbusculares, (S) esporas, (V) vesículas, (LH+HC) hifas longitudinales+enrollados hifales. Estructuras fúngicas intrarradicales de endófitos oscuros septados: (SH) hifa septada, (MS) microesclerosio. Tipo morfológico de la colonización micorrízica arbuscular: ambos (Tipos Arum y Paris) y Tipo Intermedio.

\begin{tabular}{|c|c|c|c|c|c|c|c|c|c|c|c|}
\hline SPECIES & $\%$ CM (oct) & $\% \mathrm{CM}$ (abr) & $\mathbf{A}$ & $\mathrm{HC}$ & $\mathrm{AC}$ & $\mathbf{S}$ & $\mathbf{V}$ & HL+HC & HS & MS & MT \\
\hline Aster grisebachii & 66 & 84 & $\mathrm{x}$ & $\mathrm{x}$ & & & $\mathrm{x}$ & $\mathrm{x}$ & $\mathrm{x}$ & $\mathrm{x}$ & Both + Intermediate \\
\hline Erigeron bellidiastroides & 90 & 95 & $\mathrm{x}$ & $\mathrm{x}$ & $x$ & $\mathrm{x}$ & $\mathrm{x}$ & $\mathrm{x}$ & $\mathrm{x}$ & $\mathrm{x}$ & Both + Intermediate \\
\hline Erigeron cuneifolius & 89 & 98 & $\mathrm{x}$ & $\mathrm{x}$ & $\mathrm{x}$ & $\mathrm{x}$ & $\mathrm{x}$ & & $\mathrm{x}$ & $\mathrm{x}$ & Both \\
\hline Pectis juniperina & 100 & 100 & $\mathrm{x}$ & $\mathrm{x}$ & & & $\mathrm{x}$ & & $\mathrm{x}$ & & Both \\
\hline Sachsia polycephala & 75 & 100 & $\mathrm{x}$ & $\mathrm{x}$ & $\mathrm{x}$ & $\mathrm{x}$ & $\mathrm{x}$ & & $\mathrm{x}$ & $\mathrm{x}$ & Both \\
\hline
\end{tabular}


them showed intraradical spores and arbuscular coils (Figure 1). In addition, dark septate endophytes (DSE) not corresponding to the type of arbuscular mycorrhizal structure were found in all root samples.

The identification of distinctive characteristics involved in the internal morphology of MA, hyphal coils and arbúsculos, showed that they belong to the Paris-Type and Arum-Type respectively, and both were present simultaneously in every species. Aster grisebachii and $E$. bellidiastroides showed longitudinal hyphae connected with hypal coils, structures similar to Intermediate Type according to Dickson (2004).

\section{Discussion}

The fact that all species turned out to be mycotrophic is in close correspondence with previous reports in Asteraceae, a plant family in which around to 233 species have been assessed. Form these $84 \%$ are mycotrophic and 100\% developed AM (Wang \& Qiu 2006).

Mycorrhizal condition from three of our genera was previously reported: Aster always AM, Erigeron either AM or NM (nonmycorrhizal) and Pectis AM, however, their number was small (Wang \& Qiu 2006). A. grisebachii and E. bellidiastroides were classified
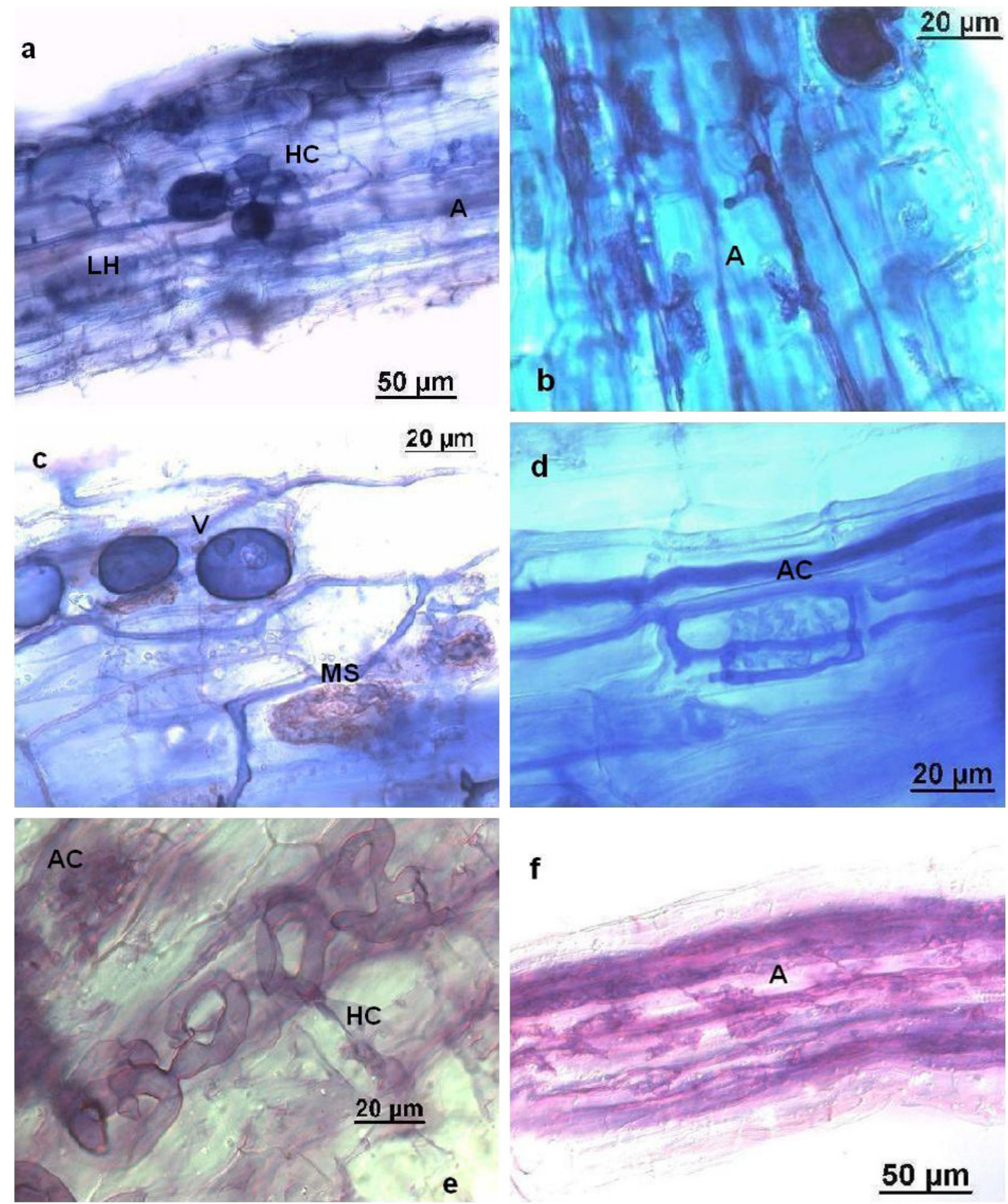

Figure 1. Arbuscular mycorrhizal colonization in studied species: a-b A.grisebachii, c-d E.bellidiastroides, e-f E. cuneifolius. AM structures: (A) arbuscules, (HC) hyphal coils, (AC) arbuscular coils and (V) vesicles; and microsclerotium (MS) characteristic of dark septate endophytes.

Figura 1. Colonización micorrízica arbuscular en las especies estudiadas: a-b A.grisebachii, c-d E.bellidiastroides, e-f E. cuneifolius. Estructuras micorríco arbusculares: (A) arbúsculos, (HC) enrollados hifales, (AC enrollados arbusculares), vesículas; y (MS) microesclerosios de Endófitos Oscuros Septados. 

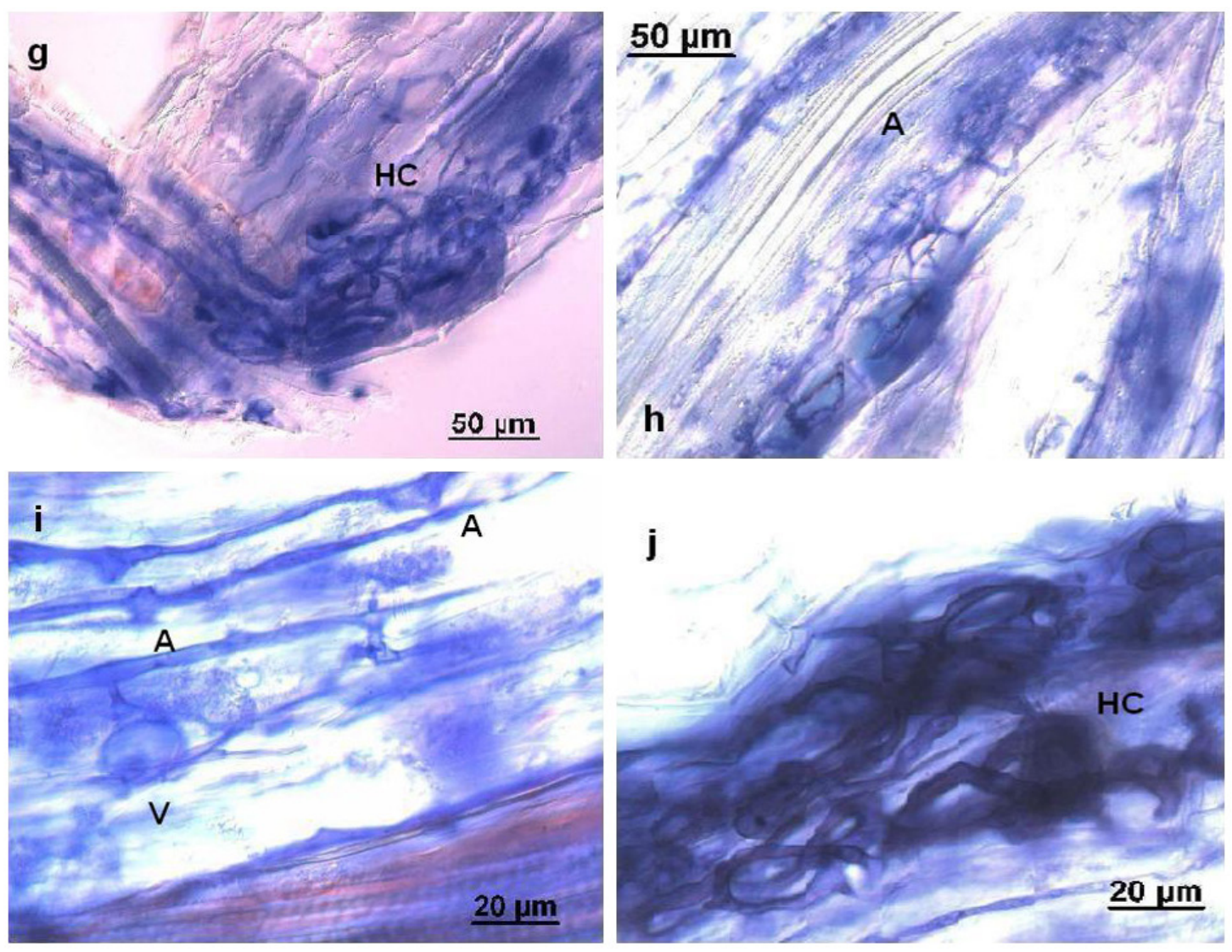

Figure 1. Arbuscular mycorrhizal colonization in studied species: g-h P.juniperinus and i-j S.polycephala. AM structures: (A) arbuscules, (HC) hyphal coils, (AC) arbuscular coils and (V) vesicles; and microsclerotium (MS) characteristic of dark septate endophytes.

Figura 1. Colonización micorrízica arbuscular en las especies estudiadas: g-h P.juniperinus and i-j S.polycephala .Estructuras micorríco arbusculares: (A) arbúsculos, (HC) enrollados hifales, (AC enrollados arbusculares), vesículas; y (MS) microesclerosios de Endófitos Oscuros Septados.

as AM by Ferrer \& Herrera (1985) near Cortés, Pinar del Río (not quantified), a which was corroborated by our assessment.

The high colonization rate in all species in both period is in agreement with the suggestion of Read et al. (1976): in environments where competitive situations are dominant, species are strongly mycorrhizal and values of mycorrhizal colonization over and higher than $50 \%$ should be usual, at both (i) level of species and (ii) individual plants in any habitat and as a general rule.

The simultaneous occurrence of both morphologies (ArumType and Paris-Type) in the same species has been reconsidered as intermediate by Dickson (2004), who has claimed that a continuum of structures exists between these two types. However, consistent reports about this subject generally refer to studies done with a single species of AMF (inoculated) where intermediate morphology is well defined. Thus we sugest to keep both types apart since in our study all species were growing under natural conditions with mixed source of AMF. Therefore we cannot be sure that they belong to a single fungus. Only species with longitudinal hypha connected to hyphal coils, structures similar to the Intermediate Type were considered as such, but both types (Arum and Paris) were observed simultaneously in all species. Experiments of Kubota et al. (2005) proved that both morphologies can occur in a single root system when plants are grown in soils with mixed fungal inoculum.

Yamato (2004) found in six Asteraceae species in vacant lands, a typical Arum-type morphology and included Erigeron genus, the same as Shah et al. (2009) that found that in 12 invasive Asteraceae in the Himalayas showed Arum-Type only. In contrast with our results, the most studies performed so far this family has been reported as having the Arum-Type (49 out of the 51 genera which they had revised), and only one genus had both morphologic types (Dickson et al. 2007).

Several factors influence the AM structure: plant genome, fungus genome, environmental conditions and the combination of all these (Smith 1995, Bedini et al. 2000, Cavagnaro et al. 2001, Ahulu et al. 2005). In our assessment every species from a single family under similar edaphic-climatic conditions and with a mixed source of AMF exhibited both morphologies simultaneously and two Intermediate Type. The experiments of Cavagnaro et al. (2001) in tomato with six species of AMF showed that both morphologies can be observed in a single host depending on the guest fungal species. Husband et al. (2002) and Geue \& Hock (2004) showed that a plant species can be colonized by more than one AMF in a given area or ecosystem. Even though the determinant factor in the formation of AM structures is not at all clear, our research shows that the fungus can play a major role in AM establishment and also that a plant genus or species can have both morphologies simultaneously in a given ecosystem. Dickson (2004) shows that the division of mycorrhizal structure in Arum and Paris based on plant families can be confusing and Dickson et al. (2007) recognize that both types and their combinations occur frequently in the mayor taxa, although one type is predominant in many individual family. However, we considered that the categorical classification of the botanical families according to the MA morphologic types is yet unreliable most of all when the number evaluated genera and/ or species are not representative of the family and/or the number of habitat or of individuals is equally limited.

In this study DSE were observed co-occurring with AM fungi in all species, but they were not quantified. Recent studies report the co- 
occurrence of DSE and AMF and suggest that it is common in plant roots in nature (Rains et al. 2003, Muthukumar et al. 2006, SantosGonzalez et al. 2007, Mandyam \& Jumpponen 2008, Khidir et al. 2010, Yang et al. 2010) and some of them suggest that colonization of roots can be interfered by non-mycorrhizal endophytes, especially during the hot season which corresponds to the plant growing season when water availability is low and that a competition between both endophytes during colonization could limit the distribution of AM in dry region (Mandyam \& Jumpponen 2008, Khidir et al. 2010, Yang et al. 2010).

This relation has not been clarified yet; therefore, further studies are needed for resolving the existing relations between both fungal endophytes.

This is a first report of morphological AM types and DSE in Cuban plants and further studies are also necessary to know a diversity, co-occurrence and distribution of both fungal communities in plants and Cuban ecosystems.

\section{Acknowledgments}

The authors thank Lázaro Hernández (conservation's worker) of RFM San Ubaldo-Sabanalamar. We acknowledge the financial support of frame of the net AMFOODS "Functional links between aboveground changes and belowground activity with land use in the Americas" between 2006-2012.

\section{References}

AHULU, E.M., NAKATA, M. \& NONAKA, M. 2005. Arum and Paris-type of arbuscular mycorrhiza in a mixed pine forest on sand dune soil in Niigata Prefecture, central Honshu, Japan. Mycorrhiza 15:129-136. http://dx.doi. org/10.1007/s00572-004-0310-9

BEDINI, S., MAREMMANI, A. \& GIOVANNETTI, M. 2000. Paristype mycorrhizas in Smilax aspera L. growing in a Mediterranean scherophyllous wood. Mycorrhiza 10:9-13. http://dx.doi.org/10.1007/ s005720050281

BORHIDI, A. 1996. Phytogeography and Vegetation Ecology of Cuba. Akadémiai Kiadó, Budapest.

BRUNDRETT, M.C. 2002. Coevolution of roots and mycorrhizas of land plants. New Phytol. 154:275-304.

CAVAGNARO, T.R., GAO, L-L., SMITH, F.A. \& SMITH, S.E. 2001. Morphology of arbuscular mycorrhiza is influenced by fungal identity. New Phytol. 151:469-475.

DICKSON, S. 2004. The Arum-Paris continuum of mycorrhizal symbioses New Phytol. 163:187-200. http://dx.doi.org/10.1111/j.14698137.2004.01095.x

DICKSON, S., SMITH, F.A. \& SMITH, S. 2007. Structural difference in arbuscular mycorrhizal symbioses: more than 100 years after Gallaud, where next? Mycorrhiza 17:375-393. http://dx.doi.org/10. 1007/s00572007-0130-9

FERRER, R.L. \& HERRERA, R.A. 1985. Especies micorrízicas cubanas. Rev. Jardín Bot. Nac. 6(1):75-78.

FERRER, R.L. \& HERRERA, R.A. 1988. Micotrofía en Sierra del Rosario. In Ecología de los Bosques Siempreverdes de Sierra del Rosario, Cuba. (R.A. Herrera, L. Menéndez, M.E. Rodríguez \& E.E. García, eds.). p.473-484.

GEUE, H. \& HOCK, B. 2004. Determination of Acaulospora longula and Glomus subgroup Aa in plant roots from grassland using new primers against the large subunit ribosomal DNA. Mycol.Res. 108(1):76-78. http://dx.doi.org/10.1017/S0953756203009080

GIOVANNETTI, M. \& MOSSE, B. 1980. An evaluation of techniques to measure vesicular-arbuscular infection in roots. New Phytol. 84:489-500.
HUSBAND, R., HIERRE, E.A., TURNER, S.L., GALLERYS, R. \& YOUNG, J.P. 2002. Molecular diversity of arbuscular fungi and patterns of host association over time and space in a tropical forest. Molecular Ecol. 11:2669-2678.

KHIDIR, H.H., EUDY, D.M., PORRAS-ALFARO, A., HERRERA, J., NATVIG, D.O. \& SINSABAUGH, R.L. 2010. A general suite of fungal endophytes dominate the roots of two dominant grasses in a semiarid grassland. J Arid Environ 74:35-42. http://dx.doi.org/10.1016/j. jaridenv.2009.07.014

KUBOTA, M., McGONIGLE, T.P. \& HYAKUMACHI, M. 2005. Coocurrence of Arum- and Paris-type morphologies of arbuscular mycorrhizae in cucumber and tomato. Mycorrhiza 15:73-77. http://dx.doi. org/10.1007/s00572-004-0299-0

MANDYAM, K. \& JUMPPONEN, A. 2008. Seasonal and temporal dynamics of arbuscular mycorrhizal and dark septate endophytic fungi in a tallgrass prairie ecosystem are minimally affected by nitrogen enrichment. Mycorrhiza 18:145-155. http://dx.doi.org/10.1007/s00572-008-0165-6

MUTHUKUMAR, T., SENTHILKUMAR, M., RAJANGAM, M. \& UDAIYAN, K. 2006 Arbuscular mycorrhizal morphology and dark septate fungal associations in medicinal and aromatic plants of Western Ghats, Southern India. Mycorrhiza 17:11-24. http://dx.doi.org/10.1007/ s00572-006-0077-2

PHILLIPS, J.M. \& HAYMAN, D.S. 1970. Improved procedures for clearing roots and staining parasitic and vesicular-arbuscular mycorrhizal fungi for rapid assessment of infection. Trans. Brr. Mycol. Soc. 55:158-161.

RAINS, K.C., NADKARNI, N.M. \& BLEDSOE, C.S. 2003. Epiphytic and terrestrial mycorrhizas in a lower montane Costa Rican cloud forest. Mycorrhiza 13:257-264. http://dx.doi.org/10.1007/s00572-003-0224-y

READ, D.J., KOUCHEKI, H.K. \& HODGSON, J. 1976. Vesicular-arbuscular mycorrhiza in natural vegetation systems. I-The occurrence of infection. New Phytol. 77:641-653.

SANTOS-GONZALEZ, J., FINLAY, R. \& TEHLER, A. 2007. Seasonal dynamics of arbuscular mycorrhizal fungal communities in roots in a seminatural grassland. Appl Environ Microbiol 73:5613-5623.

SHAH, M.A., RESHI, Z.A. \& KHASA, D. 2009. Arbuscular mycorrhizal status of some Casimir Himalayan alien invasive plants. Mycorrhiza 20:67-72. http://dx.doi.org/10.1 007/s00572-009-0258-x

SMITH, S.E. 1995. Discoveries, Discussions and directions of micorrhizal researches. In Mycorrhiza: structure, funtion, molecular biology and biotechnology (A. Varma \& B. Hock, eds.). Springer-Verlag, Berlin, p.3-24.

SMITH, F.A. \& SMITH, S.E. 1997. Structural diversity in (vesicular)arbuscular mycorrhizal symbioses. New Phytologist 137:373-388.

TRAPPE, J.M. 1981. Mycorrhizae and Productivity of Arid and Semiarid Rangelands. Acad. Press, Inc., New York, p.581-599.

URQUIOLA, A.J., GONZÁLEZ-OLIA, L., NOVO, R. \& ACOSTA, Z. 2010. Libro rojo de la flora vascular de la provincia de Pinar del Río. Jardín Botánico de Pinar del Río, Cuba. Publicaciones Universidad de Alicante, Alicante, $457 \mathrm{p}$.

WANG, B. \& QIU, Y-L. 2006. Phylogenetic distribution and evolution of mycorrhizas in land plants. Mycorrhiza16:299-363. http://dx.doi.org/10.1 007/s00572-005-0033-6

YAMATO, M. 2004. Morphological types of arbuscular mycorrhizal fungi in roots of weeds on vacant land. Mycorrhiza 14:127-131. http://dx.doi. org/10.1007/s00572-003-0246-5

YANG, C., HAMEL, C., SCHELLENBERG, M.P., PEREZ, J.C. \& BERBARA, R.L. 2010. Diversity and Functionality of Arbuscular Mycorrhizal Fungi in Three Plant Communities in Semiarid Grasslands National Park, Canada. Microb Ecol 59:724-733. http://dx.doi. org/10.1007/s00248-009-9629-2 